\title{
Characterization of Low Cost Ion Conducting Poly(AAc-co-DMAPMA) Membrane for Fuel Cell Application
}

\author{
Anup Das' ${ }^{1}$, Suddhasatwa Basu ${ }^{2 *}$, Anil Verma ${ }^{2}$, Keith Scott ${ }^{3}$ \\ ${ }^{1}$ Centre for Biomedical Engineering, Indian Institute of Technology Delhi, New Delhi, India \\ ${ }^{2}$ Department of Chemical Engineering, Indian Institute of Technology Delhi, New Delhi, India \\ ${ }^{3}$ Department of Chemical Engineering and Advance Material, Newcastle University upon Tyne, Newcastle, UK \\ Email: sbasu@iitd.ac.in
}

Received 16 February 2015; accepted 7 March 2015; published 10 March 2015

Copyright (C) 2015 by authors and Scientific Research Publishing Inc.

This work is licensed under the Creative Commons Attribution International License (CC BY). http://creativecommons.org/licenses/by/4.0/

\section{(c) (i) Open Access}

\section{Abstract}

Poly(AAc-co-DMAPMA) membrane (PADMA) is synthesized by free radical aqueous copolymerization of acrylic acid (AAc) and $N$-3-[dimethylamino)propyl]-methacrylamide (DMAPMA) to check its stability and conductivity. The hydrogel membrane characterized physically to study morphology by SEM, thermal stability by TGA and mechanical stability by measuring compressive strength and ionic conductivity by electrochemical impedance spectroscopy in alkaline as well as in acidic environment at different temperatures. The compression modulus of the hydrogel membrane is $24 \mathrm{kPa}$ at $\mathbf{p H}=1.0$ and $16 \mathrm{kPa}$ at $\mathrm{pH}=7.0$, and stable (no fracture) till $72 \%$ deformation. The PADMA hydrogel membrane ionic conductivity increased with the increase in temperature and structurally stable up to $190^{\circ} \mathrm{C}$. Improvement in ionic conductivity is observed after the heat treatment of the membrane. Compared with ionic conductivity of Nafion ${ }^{\circledR}$ (SE512), the PADMA membrane found to be inferior. However, the PADMA hydrogel membrane conductivity was greater $\left(\sim 1 \times 10^{-4} \mathrm{~S} / \mathrm{cm}\right)$ at low and high $\mathrm{pH}$ compared with neutral $\mathrm{pH}\left(\sim 1 \times 10^{-5} \mathrm{~S} / \mathrm{cm}\right)$ indicating the possibility of using the membrane as either a proton and hydroxyl ion conductor.

\section{Keywords}

Fuel Cells, Hydrogel Membrane, Ionic Conductivity, PEM

\section{Introduction}

Fuel cell technology has been considered as a clean source of energy compared to conventional energy convert-

"Corresponding author.

How to cite this paper: Das, A., Basu, S., Verma, A. and Scott, K. (2015) Characterization of Low Cost lon Conducting Poly(AAc-co-DMAPMA) Membrane for Fuel Cell Application. Materials Sciences and Applications, 6, $234-241$.

http://dx.doi.org/10.4236/msa.2015.63028 
ing device. Out of many types of fuel cells which are developed, proton exchange membrane fuel cell (PEMFC) is most promising in terms of efficiency in energy conversion [1]. However, high cost of PEMFC compared to conventional source of energy prohibiting it from commercialization. One of the high cost materials used in PEMFC is proton exchange membrane (PEM). Recent cost analysis shows that $12 \%$ of the total cost of the PEMFC stack is incurred by the PEM [2]. The most commonly used PEM is perfluorosulphonic acid membrane (PFSA) such as Nafion ${ }^{\circledR}$ [1]. Apart from its high cost, use of the Nafion is restricted to $90^{\circ} \mathrm{C}$. Nafion at temperature higher than $90^{\circ} \mathrm{C}$ dehydrates, which severely hampers the transport of proton in the form of hydronium ions. In recent years, there has been effort to develop new cost effective polymer electrolyte membrane (proton exchange type) for the application in PEMFC, which can be operated at high temperature.

The development of high temperature polymer electrolyte membrane fuel cells is a recent research area. The interest in the development is due to the numerous advantages of PEMFC technology operating above $100^{\circ} \mathrm{C}$ [3]-[5]: 1) kinetics of both the electrode reactions are enhanced; 2) tolerance of the Pt electrodes to carbon monoxide is increased; 3) non-noble metal catalysts may be used; 4) the integration of reformer technology is simpler; and 5) the cooling system for facilitating heat dissipation can be simplified. However, the limitation of the present commercial PEMs are not suitable for the temperature higher than $100^{\circ} \mathrm{C}$. Therefore, three different types of membranes have been, and are being investigated for the fuel cell at temperature higher than $100^{\circ} \mathrm{C}: 1$ ) modified perfluorosulphonated membranes, 2) alternative sulphonated polymers and their composite and finally 3) acid-base polymer membranes and their composites. However, Nafion is still the most commonly used memebrane for low temperature PEMFC. It is necessary to develop low cost and high proton conductivity membrane.

The present study is focused on the development of a novel and low cost polymer electrolyte membrane. These are hydrogel types of membranes, and to date the hydrogel membrane is rarely applied as PEM for fuel cell application. Nikolic et al. [6] prepared the polyvinyl alcohol (PVA) hydrogels using gamma ray irradiation for the fuel cell use. The ionic conductivity of the PVA hydrogels was measured as a function of concentration of $\mathrm{KOH}$ solution and temperature. The highest ionic conductivity of the swollen PVA membrane with $6 \mathrm{M} \mathrm{KOH}$ was found to be $10 \mathrm{mS} \cdot \mathrm{cm}^{-1}$ at $25^{\circ} \mathrm{C}$. In another study, Kim et al. [7] used the hydrogel in methanol fuel cartridge for suppressing the methanol crossover in a direct methanol fuel cell. However, they have not used hydrogel as polymer electrolyte in membrane electrode assembly. Hydrogel membrane holds water and we are interested to know whether it can be used without humidifying hydrogen in PEMFC.

The present study focuses on the synthesis of the poly(AAc-co-DMAPMA) membrane (PADMA), which is cheap and easy to prepare from acrylic acid and $N$-3-[dimethylamino)propyl]-methacrylamide. The PADMA hydrogel membrane is preliminary characterized by SEM, TGA, mechanical strength, and ionic conductivity at different temperature and $\mathrm{pH}$ for the possible use as electrolyte in fuel cells.

\section{Experimental}

\subsection{Materials}

The membrane was synthesized using acrylic acid (AAc) (G.S. Chemicals, India), $N$-3-[dimethylamino) propyl]methacrylamide (DMAPMA) (Aldrich, USA), ammonium persulphate (APS) (Qualigens Fine Chemicals, India), $N, N, N^{\prime}, N^{\prime}$-tetramethyl ethylene diamine (TEMED) (SRL Pvt. Ltd, India). AAc and DMAPMA were purified before use by vacuum distillation. Other chemicals were used as received from the source.

\subsection{Synthesis of Poly(AAc-co-DMAPMA) Membrane}

The membrane was prepared by free radical aqueous copolymerization of AAc and DMAPMA; using APS and TEMED as the initiator and accelerator, respectively. The reaction, as shown in the Figure 1, was carried out with slight modification in the technique as described elsewhere [8]. Briefly, AAc and DMAPMA were mixed in a round bottomed flask, placed over magnetic stirrer in cold condition. This was followed by the addition and thorough mixing of distilled water. A typical feed composition consists of AAc, DMAPMA, and water in the ratio of $25.8 \%, 4.2 \%$, and $70 \%$ (mole). Nitrogen gas was purged into the flasks for $15 \mathrm{~min}$. followed by the addition of TEMED ( $3 \mathrm{~mol} \%$ ) and concentrated aqueous solution of APS (amounting $0.50 \mathrm{~mol} \%$ of total monomer) with continuous stirring over magnetic stirrer. After 5 minutes, the reaction mixture was transferred into a rectangular mold. The mold, $70 \mathrm{~cm} \times 80 \mathrm{~cm} \times 0.08 \mathrm{~cm}$ in dimension, was prepared using Teflon spacers along the 


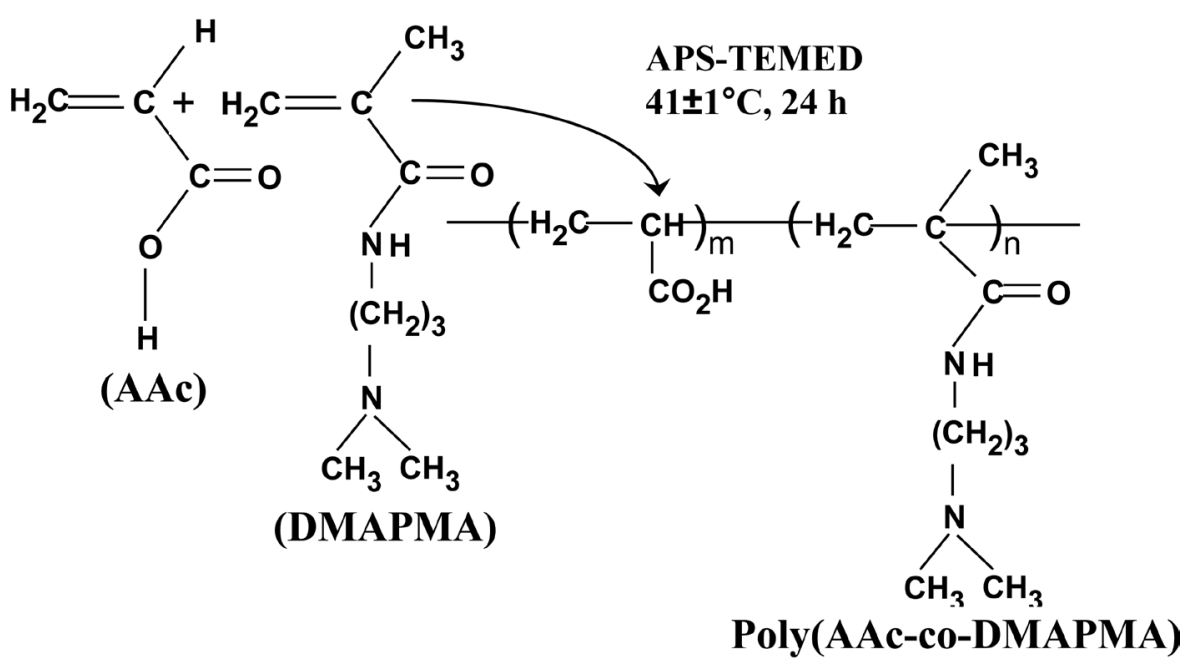

Figure 1. Synthesis of poly(AAc-co-DMAPMA) hydrogel membrane.

three edges of a pair of glass plates. The open side along the remaining edge was partially closed by a smaller spacer, leaving two orifices at the corners. Nitrogen gas was purged through one of the orifices, while the other was used to inject the reaction mixture under gentle stream of nitrogen. The mold was then placed vertically in a thermostated water bath at $41^{\circ} \mathrm{C} \pm 1{ }^{\circ} \mathrm{C}$ and dipped up to the height of reaction mixtures. Nitrogen purging was stopped after 15 min and the orifices were closed using paraffin grease. After $24 \mathrm{~h}$, the PADMA membrane was removed from the mold, cut into pieces, washed in regularly changed distilled water for 3 days to remove the unreacted monomers, and dried in vacuum. The thickness of the membrane was $830 \mu \mathrm{m}$.

\subsection{Characterization of the Membrane}

\subsubsection{Scanning Electron Microscopy (SEM)}

ZEISS EVO Series scanning electron microscope (Model EVO 50) was used to investigate the morphology of the membrane. To evaluate the morphology, the membrane was swollen in an appropriate solution. The swollen sample was lyophilized to remove any solvent or water from the sample and kept in vacuum till silver sputtering treatment.

\subsubsection{Thermo Gravimetric Analysis}

The thermal stability of the membrane was investigated using a PerkinElmer Pyris 6 TGA with a heating rate of $20^{\circ} \mathrm{C} / \mathrm{min}$ from $25^{\circ} \mathrm{C}$ to $800^{\circ} \mathrm{C}$.

\subsubsection{Mechanical Strength}

Uniaxial compression is a useful technique to evaluate the mechanical strength of the polymer electrolyte membranes, especially hydrogels. TA-XT2i Texture Analyzer (Stable Micro Systems, UK), with a 5 kg load cell was used to analyze the compressive strength of the hydrogel. The force measurements accuracy and the distance resolution of the instruments were $0.0025 \%$ and $0.0025 \mathrm{~mm}$, respectively. The membrane was separately equilibrated in buffered solution of $\mathrm{pH} 1.0$ and 7.0. Circular discs of $15 \mathrm{~mm}$ diameter were punched off with the help of a sharp edged puncher. Uniaxial compression experiment was performed on the cut sample of the swollen membrane at $25^{\circ} \mathrm{C}$. Cylindrical aluminium probe with a diameter of $35 \mathrm{~mm}$ was used for compression. The pretest speed, test speed and post-test speed were set up at $2.00 \mathrm{~mm} / \mathrm{s}, 1.00 \mathrm{~mm} / \mathrm{s}$ and $1.00 \mathrm{~mm} / \mathrm{s}$ respectively, with an acquisition rate of 200 points/s. The force necessary for compressing the discs at $0.8 \mathrm{~mm}$ was recorded. The stress values $(\sigma)$ were determined using Equation (1) [9].

$$
\sigma=\frac{F}{A}
$$

where, $F$ is the force and $A$ is the cross-sectional area of the strained specimen. The parameters generated by the 
instrument were force and time/displacement. Those information were then converted to elastic modulus, $E$, by using following Equation (2).

$$
\sigma=E\left(\lambda-\lambda^{-2}\right)
$$

$E$ was determined from the slope of the stress-strain relationship. The macroscopic deformation ratio $(\lambda)$ was calculated as $\lambda=L_{t} / L_{0}$. Here, $L_{t}$ and $L_{0}$ are the length of the deformed and undeformed specimen respectively.

\subsubsection{Ionic Conductivity of the Membrane}

Ionic conductivity of the membrane was measured in a conductivity cell in which a strip of the membrane was placed in between two pair of platinum strips separated by $0.5 \mathrm{~cm}$. The bulk conductivity of the hydrogel and Nafion ${ }^{\circledR} 512$ membrane was measured using frequency response analyser (FRA). AC impedance measurements were carried out between $100 \mathrm{~Hz}$ and $30 \mathrm{kHz}$. The thickness of the PADMA membrane was $625 \mu \mathrm{m}$ after pressing and that of Nafion ${ }^{\circledR} 512$ was $133 \mu \mathrm{m}$. The platinum strips acted as connector for resistance measurement. The top and bottom cover of the conductivity cell is attached with plate heater to measure conductivity with the variation of temperature. The hydrogel membrane was held in the conductivity cell at the desired temperature to reach the steady state before every measurement. The details of the conductivity measurement cell and technique of measurement is given in [5] [10]. The conductivity of the membrane was measured at different temperatures after soaking the membranes in different $\mathrm{pH}$ buffer solutions (pH: 2.3/6/8/10.36). The membranes were washed with de-ionized water before every measurement. The buffers of various $\mathrm{pH}$ values were prepared according to the standard methods [11]. Depending on the type of reagents used, the buffers were divided in three categories as listed in Table 1. The membrane conductivities were measured in dry condition (RH 39\%). We treated the situation of water starved anode as a limiting condition and tried to evaluate what happens when the hydrogel and PEM do not have enough water at increased temperature. Thus the conductivity results are evaluated at the limiting condition and compared with the Nafion ${ }^{\circledR}$ in similar situation. The experimental measurement using FRA was repeated and an average value is reported. The error in conductivity measurement is $\sim 3 \%$.

\section{Results and Discussion}

\subsection{Morphology}

SEM micrographs of the membrane are shown in Figure 2. Figure 2(a) reveals that the interior of the membrane is macroporous and has enough space to accommodate water or suitable electrolyte. Interestingly the surface, unlike interior, appears to be nonporous. Figure 2(b) gives a closure look of the surface. Here, the micrograph was captured at $40 \mathrm{kx}$ magnification to observe the building blocks. It shows that the swollen membrane surface is quite dense and is made up of closely packed nanogels of $\sim 300 \mathrm{~nm}$ diameter. The morphology of the membrane indicates that it may be useful for the fuel cell application as the dense surface may not allow the fuel to pass through and at the same time the inner structure may help to improve the conductivity. The morphology of PADMA hydrogel membrane indicates that its matrix may be used similar to polybenzimidazole membrane soaked in phosphoric acid [10].

\subsection{Thermal Stability}

Figure 3 shows the TGA and DTA thermograms of the PADMA membrane. The DTA curve ensures that the membrane undergoes two-step thermal degradation. The first degradation step starts at $\sim 190^{\circ} \mathrm{C}$ and ranges up to

Table 1. Reagents used to prepare different buffer solutions. Buffer A: $50 \mathrm{~mL} 0.2 \mathrm{M} \mathrm{KCl}+$ vol of HCL as indicated in table 1; Buffer B: $100 \mathrm{~mL} 0.1 \mathrm{M} \mathrm{KH}_{2} \mathrm{PO}_{4}+$ vol of $\mathrm{NaOH}$ as indicated in table; Buffer C: $100 \mathrm{~mL} 0.025 \mathrm{M} \mathrm{Na}_{2} \mathrm{~B}_{4} \mathrm{O}_{7} \cdot 10 \mathrm{H}_{2} \mathrm{O}$ (borax) + vol of $\mathrm{NaOH}$ as indicated in Table 1.

\begin{tabular}{|c|c|c|c|c|c|}
\hline \multicolumn{2}{|c|}{ Buffer A } & \multicolumn{2}{|c|}{ Buffer B } & \multicolumn{2}{|c|}{ Buffer C } \\
\hline $\mathrm{pH}$ & $\begin{array}{l}0.2 \mathrm{M} \mathrm{HCl} \\
(\mathrm{mL})\end{array}$ & $\mathrm{pH}$ & $\begin{array}{c}0.1 \mathrm{M} \mathrm{NaOH} \\
(\mathrm{mL})\end{array}$ & $\mathrm{pH}$ & $\begin{array}{c}0.1 \mathrm{M} \mathrm{NaOH} \\
(\mathrm{mL})\end{array}$ \\
\hline \multirow[t]{2}{*}{2.00} & 13.0 & 6.00 & 11.2 & 10.00 & 36.6 \\
\hline & & 8.00 & 93.4 & & \\
\hline
\end{tabular}



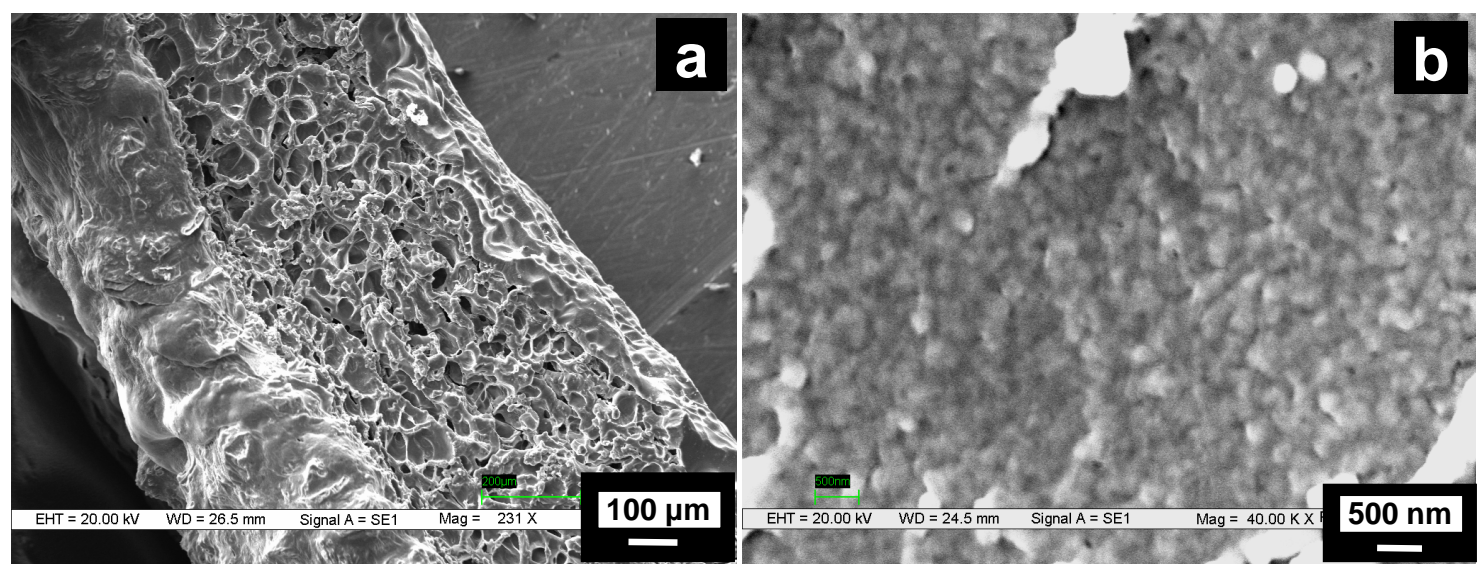

Figure 2. SEM micrographs of swollen PADMA membrane: (a) Shows the cross section as well as the surface of the membrane; (b) Shows the surface of the membrane at higher magnification.

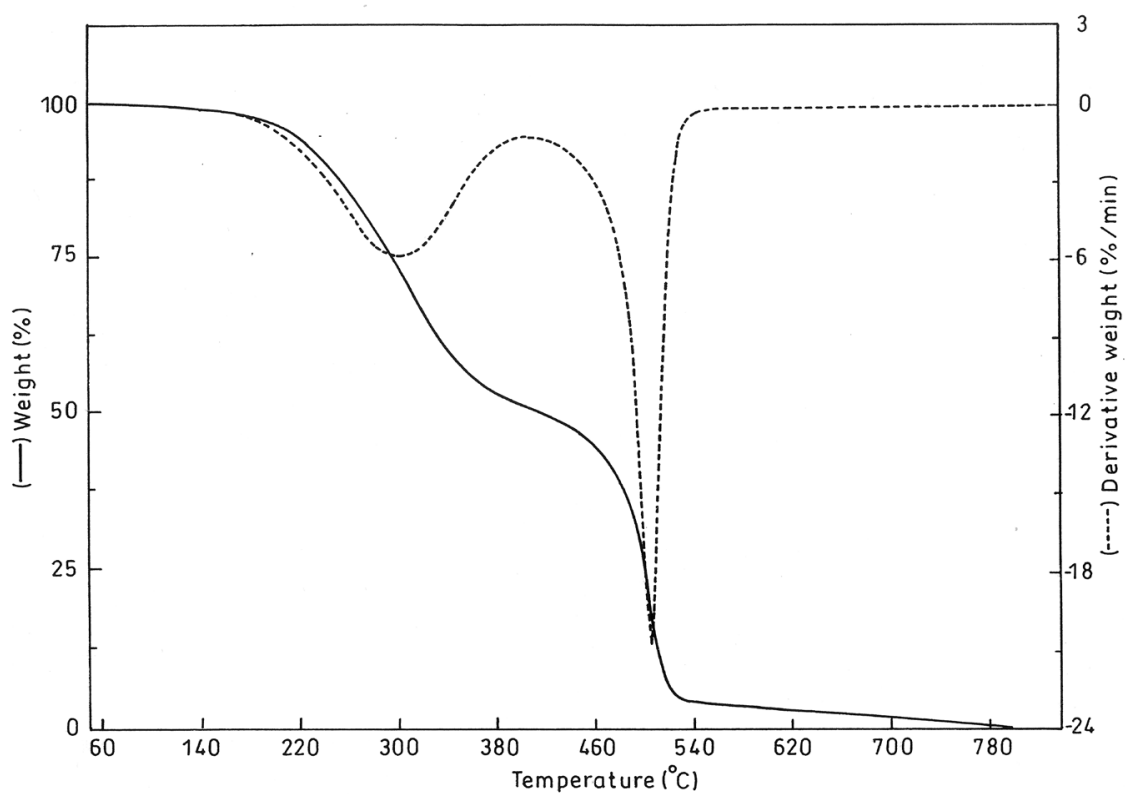

Figure 3. Thermogravimetric and differential thermogravimetric curves for PADMA membrane.

$380^{\circ} \mathrm{C}$. This is most probably due to the degradative reactions involving the pendant groups in the polymer chains, such as decarboxylation. The TGA thermogram indicates that the membrane loses $\sim 50 \%$ of its weight at this stage. The second step of weight loss, most probably due to back bone degradation, starts at $\sim 400^{\circ} \mathrm{C}$. Therefore, PADMA membrane can be safely used up to $190^{\circ} \mathrm{C}$.

\subsection{Mechanical Strength}

Compression experiment was done to determine the system hardness $\left(F_{\max }\right)$ and compressive elastic modulus $(E)$. Profiles obtained from a typical experiment with the swollen PADMA membrane at pH 1.0 and 7.0 are shown in Figure 4. Each of the curves in Figure 4 has two halves. The ascending half is due to the stress applied onto the membranes. The peak denotes the maximum stress applied $\left(F_{\max }\right)$ at $0.8 \mathrm{~mm}$ compression. The descending half in individual curves is due to the withdrawal of stress from the membranes. PADMA membrane of $0.8 \mathrm{~mm}$ thickness under compression at $\mathrm{pH} 1.0$ resulted in $~ 72 \%$ deformation. No fracture was observed in the experimental range and the PADMA disc was found to revert back to its original shape and size on stress withdrawal. Compressive strength $\left(F_{\max }\right)$ of the swollen membrane at $\mathrm{pH} 1.0$ and 7.0 was found to be $\sim 85 \mathrm{kPa}$ and $34 \mathrm{kPa}$, 


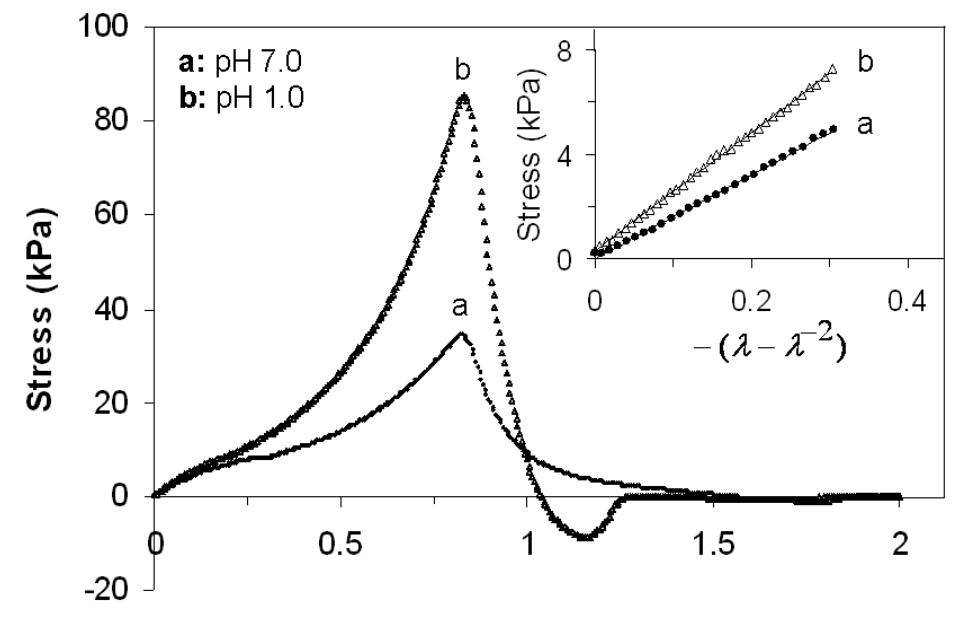

Time (s)

Figure 4. Typical stress-displacement curves of PADMA membrane equilibrated in buffer of $\mathrm{pH} 7.0$ (a) and $\mathrm{pH} 1.0$ (b). Maximum deformation with each sample being $0.8 \mathrm{~mm}$. Inset: Respective stress-strain curves.

respectively at $0.8 \mathrm{~mm}$ compression.

Linear stress-strain relationship was observed at low strain, and is shown as inset. The elastic modulus (E) of the membrane was found to be around $24 \mathrm{kPa}$ and $16 \mathrm{kPa}$ at $\mathrm{pH} 1.0$ and $\mathrm{pH}$ 7.0, respectively. During the operation of a fuel cell, electrodes are pressed against the polymer electrolyte membrane, and this put the polymer under compressive stress. The elastic modulus of the well known nafion membrane ranges from 0.5 MPa to 1.28 MPa for different testing conditions [12]. The lower elastic modulus of the prepared membrane seems to be inferior in comparison to the nafion membrane. However, high compressibility of PADMA membrane due to its viscoelastic nature may compensate the inferior modulus during application in fuel cell.

\subsection{Ionic Conductivity}

Figure 5 shows the ionic conductivity of the membrane measured as a function of $\mathrm{pH}$ and temperature. It is seen in Figure 5 that the conductivity of the PADMA hydrogel membrane decreases with the increase in $\mathrm{pH}$ from 2.2 till $\mathrm{pH} 6$ and then increases with the further increase in $\mathrm{pH}$ to 10.6. At $80^{\circ} \mathrm{C}$, the conductivity of the PADMA membrane decreases from $6.2 \times 10^{-5}$ to $2.8 \times 10^{-5} \mathrm{~S} / \mathrm{cm}$ with the increase of $\mathrm{pH}$ from 2.2 to 6 and then increases to $1 \times 10^{-4} \mathrm{~S} / \mathrm{cm}$ with the further increase in $\mathrm{pH}$ to 10.6. The increase in ionic conductivity of PADMA membrane at low $(=2.2)$ and high $(=10.6) \mathrm{pH}$ indicates that the membrane may work both as proton and hydroxyl ion conductor. Recently, Unlu et al. [13] and Hickner [14] reported studies on composite hybrid membrane with the formation of water at the interface of AEM/PEM membranes and polymers functionalized with sulfonic acid and quaternary ammonium hydroxide groups. PADMA hydrogel membrane prepared is not a hybrid membrane. The reason for higher ionic conductivity at low and high $\mathrm{pH}$ may be because of the presence of carboxylic (anionic) and ammonia (cationic) group in the polymeric structure of the membrane. The cationic and anionic functional groups of PADMA membranes are shown in Figure 6. It is depicted how PADMA hydrogel membrane changes from cationic to anionic with the change in $\mathrm{pH}$. The ionic conductivity of the PADMA is compared with the commercial Nafion ${ }^{\circledR} 512$ membrane. In the similar experimental conditions, the ionic conductivity of the nafion membrane decreases with the increase in the temperature beyond $100^{\circ} \mathrm{C}$ and no appreciable change in conductivity is observed with $\mathrm{pH}$. The ionic conductivity of the PADMA membrane increases with temperature and it is highest $\left(\sim 2 \times 10^{-4} \mathrm{~S} / \mathrm{cm}\right)$ at $80^{\circ} \mathrm{C}$. To study the effect of the temperature, the PADMA membrane was heat treated at around $150^{\circ} \mathrm{C}$ for few minutes and the membrane was again tested for the ionic conductivity using similar procedure. Surprisingly, ionic conductivity of the heat treated membrane was improved as compared to untreated membrane. The ionic conductivity of the heat treated membrane reaches as high as $2.17 \times 10^{-4} \mathrm{~S} / \mathrm{cm}$ at a pH of 10.4 as compared to $9.76 \times 10^{-5} \mathrm{~S} / \mathrm{cm}$ for untreated membrane at the same $\mathrm{pH}$ and temperature $\left(80^{\circ} \mathrm{C}\right)$. It 


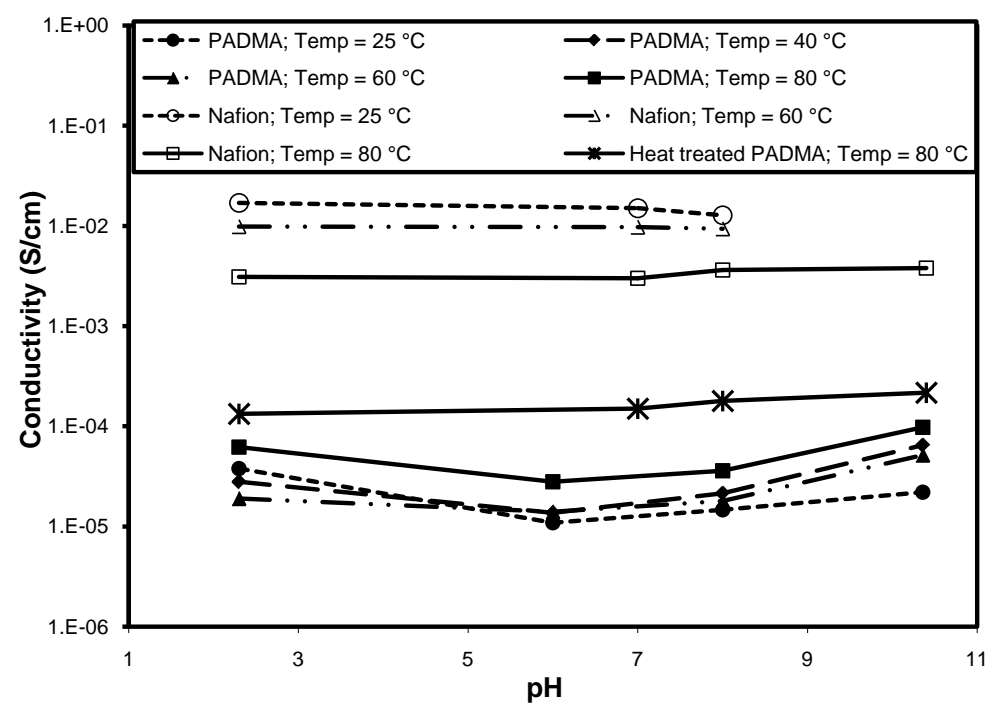

Figure 5. Ionic conductivity of the PADMA membrane and Nafion ${ }^{\circledR}$ at different temperature and $\mathrm{pH}$.

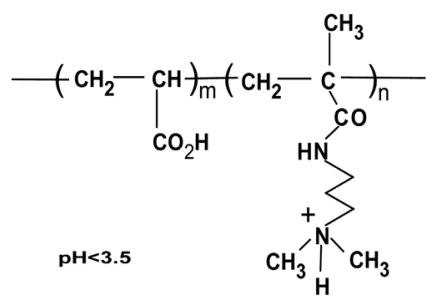

(a)

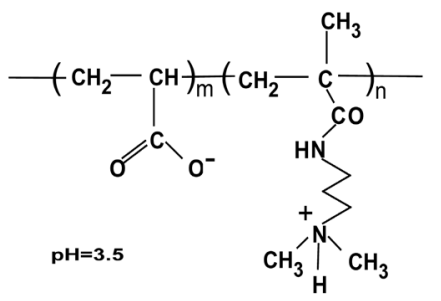

(b)

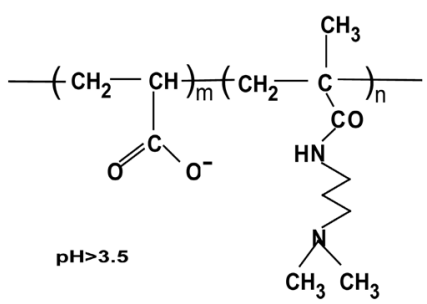

(c)

Figure 6. Predominant molecular composition of PADMA membrane in buffers of various pH values: (a) $\mathrm{pH}<3.5$; (b) $\mathrm{pH}=$ 3.5; (c) $\mathrm{pH}>3.5$.

has been shown that the hydrogel comprising DMAPMA units are temperature sensitive [15] and it would be interesting to investigate further the effect of temperature on the hydrogel membrane morphology and mechanism of ion transfer. As for Nafion and other PEM membrane, it is primarily the ion exchange procedure, which protons exchange with the sulfonate groups and the transfer of ions takes place. In the case of PADMA hydrogel membrane, it may be due to ion exchange and diffusion of ions through membrane by which ion transfer takes place.

\section{Conclusion}

The PADMA hydrogel membrane is synthesized for the possible use in fuel cells as electrolyte. The morphological analysis shows that the membrane surface is composed of fused nanogels and the inner part of the membrane has porous and spongy structures. The PAMDA membrane is thermally stable up to $190^{\circ} \mathrm{C}$ and possesses excellent compressive strength. The ionic conductivity of PADMA membrane is measured as $9.76 \times 10^{-5} \mathrm{~S} / \mathrm{cm}$ at $80^{\circ} \mathrm{C}$ and $\mathrm{pH} 10.4$. After heat treatment, the membrane conductivity increases to $2.17 \times 10^{-4} \mathrm{~S} / \mathrm{cm}$ at the same temperature $\left(80^{\circ} \mathrm{C}\right)$ and $\mathrm{pH}(10.4)$. The ionic conductivity of the PADMA membrane increases with the increase in temperature. The higher ionic conductivity at low $(=2.2)$ and high $\mathrm{pH}(=10.6)$ indicates that the membrane may be used both as proton and hydroxyl ion conductor.

\section{Acknowledgements}

Authors would like to acknowledge financial support of UK India Education Research Initiative, Department of Science and Technology, Govt. of India. 


\section{References}

[1] Dhathathreyan, K.S. and Rajalaxmi, N. (2007) Polymer Electrolyte Membrane Fuel Cell. In: Basu, S., Ed., Recent Trends in Fuel Cell Science and Technology, Springer, New York, 40-115. http://dx.doi.org/10.1007/978-0-387-68815-2_3

[2] Kamarudin, S.K., Daud, W.R.W., Som, A.Md., Takriff, M.S. and Mohammad, A.W. (2006) Technical Design and Economic Evaluation of a PEM Fuel Cell System. Journal of Power Sources, 157, 641-649. http://dx.doi.org/10.1016/j.jpowsour.2005.10.053

[3] Lobato, J., Canizares, P., Rodrigo, M.A., Linares, J.J., Aguilar, J.A. (2007) Improved Polybenzimidazole Films for $\mathrm{H}_{3} \mathrm{PO}_{4}$-Doped PBi-Based High Temperature PEMFC. Journal of Membrane Science, 306, 47-55. http://dx.doi.org/10.1016/j.memsci.2007.08.028

[4] Scott, K., Pilditch, S. and Mamlouk, M. (2007) Modelling and Experimental Validation of a High Temperature Polymer Electrolyte Fuel Cell. Journal of Applied Electrochemistry, 37, 1245-1259. http://dx.doi.org/10.1007/s10800-007-9414-1

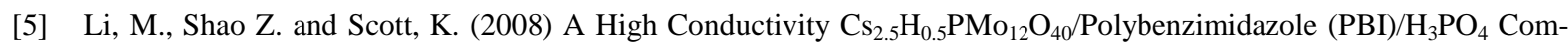
posite Membrane for Proton-Exchange Membrane Fuel Cells Operating at High Temperature. Journal of Power Sources, 183, 69-75. http://dx.doi.org/10.1007/s10800-007-9414-1

[6] Nikolic, V.M., Kekljes, A., Popovic, Z.K., Lausevic, Z.V. and Miljanic, S.S. (2007) On the Use of Gamma Irradiation Crosslinked PVA Membranes in Hydrogen Fuel Cells. Electrochemistry Communications, 9, 2661-2665. http://dx.doi.org/10.1016/j.elecom.2007.08.022

[7] Kim, W.J., Choi, H.G., Lee, Y.K., Nam, J.D., Cho, S.M. and Chung, C.H. (2006) Hydrogels in Methanol Fuel Cartridge Used as a Diffusion-Rate-Controlling Agent Suppressing the Methanol Crossover in Passively Operated FlatPack Type DMFCs. Journal of Power Sources, 157, 193-195. http://dx.doi.org/10.1016/j.jpowsour.2005.07.033

[8] Das, A. and Ray, A.R. (2008) Synthesis and Characterization of Poly(acrylic acid-co-N-[3-(dimethylamino)propyl]methacrylamide) Hydrogel Membranes for Biomedical Applications. Journal of Applied Polymer Science, 108, 12731280. http://dx.doi.org/10.1002/app.27665

[9] Muniz, E.C. and Geuskens, G. (2001) Compressive Elastic Modulus of Polyacrylamide Hydrogels and Semi-IPNs with Poly(N-isopropylacrylamide. Macromolecules, 34, 4480-4484. http://dx.doi.org/10.1021/ma001192l

[10] Verma, A. and Scott, K. (2010) Development of High Temperature PEMFC Based on Heteropolyacids and Polybenzimidazole. Journal of Solid State Electrochemistry, 14, 213-219. http://dx.doi.org/10.1007/s10008-008-0678-0

[11] Robinson, R.A. and Stokes, R.H. (1968) Electrolyte Solutions. 2nd Edition, Butterworths, London.

[12] Kawano, Y., Wang, R.A. and Palmer, S.R. (2002) Stress-Strain Curve of Nafion Membranes. Polimeos: Ciencia e Technologia, 12, 96-101.

[13] Unlu, M., Zhou, J. and Kohl, P.A. (2009) Hybrid Anion and Proton Exchange Membrane Fuel Cells. The Journal of Physical Chemistry C, 113, 11416-11423.

[14] Hickner, M.A., Tudryn, G.J., Alam, T.M., Hibbs, M.R. and Fujimoto, C.H. (2009) Polymers with Tethered Anionic and Cationic Groups as Membranes for Fuel Cells. Macromolecular Symposia, 279, 59-62. http://dx.doi.org/10.1002/masy.200950509

[15] Caykara, T., Demiray, M. and Güven, O. (2005) Effect of Type and Concentration of Surfactants on Swelling Behavior of Poly[N-[3-(dimethylamino) propyl]methacrylamide-co-N,N-methylenebis (acrylamide)] Hydrogels. Colloid and Polymer Science, 284, 258-265. http://dx.doi.org/10.1007/s00396-005-1365-7 